\title{
Antagonism of fungi with biocontrol potential of papaya black spot caused by Asperisporium caricae
}

\author{
Janieli Maganha Silva Vivas*, Silvaldo Felipe da Silveira, Pedro Henrique Dias dos Santos, Beatriz Murizini \\ Carvalho, Tathiane Pastana de Sousa Poltronieri, Tiago Silva Jorge, Juliana Saltires Santos, Railan do \\ Nascimento Ferreira Kurosawa, Ramon de Moraes
}

\author{
Agricultural Sciences and Technologies Center, Universidade Estadual do Norte Fluminense Darcy Ribeiro, 28013- \\ 602, Campos dos Goytacazes, RJ, Brazil
}

\section{*Corresponding author: janielims19@yahoo.com.br}

\begin{abstract}
The antifungal activity of fungi with biocontrol potentials should be studied. Therefore, this study aimed at establishing alternative agent to replace the chemical control of papaya black spot. We investigated the antagonistic activity of the fungi Hansfordia pulvinata (H-611), Acremonium sp (A-602, A-617 and A-598), Simplicillium lanosoniveum (S-599), Lecanicillium lecanii (L-622), and Sarocladium implicatum (I-609) on the phytopathogenic fungus $A$. caricae, by evaluating the mycoparasitism, the enzymatic activity and the production of volatile and non-volatile compounds. For the evaluation of mycoparasitism, each antagonic fungi isolate was microcultured along with conidia of $A$. caricae. Then, events of mycoparasitism were evaluated at $24 \mathrm{~h}, 48 \mathrm{~h}, 72 \mathrm{~h}$, and $96 \mathrm{~h}$ after inoculation under an optical microscope. We estimated the enzymatic activity (protease and lipase) of the fungi in a particular culture medium for each enzyme. The activity of the protease was reflected in the mean diameter of the halo. The lipase activity was measured by the halo/colony relation. In order to detect volatile compounds in the antibiosis test, $A$. caricae was cultured under a medium along with the isolates described. For the test of non-volatile compounds, we evaluated the germination of $A$. caricae in culture medium by diffusion under cellophane paper. As a result, the mycoparasitism of the H-611, A-602, A-617, A-598, S-599, and L-622 isolates was confirmed on the microcultures. We observed higher activities of protease in the I-609, S-599, A-602, and A-598 isolates. The H-611 and A-602 isolates presented higher activities for lipase. We did not observe effect of volatile compounds in any of the tested isolates. In the non-volatile compound test, there was production of antifungal metabolite highlighting the A- 617 isolate, which inhibited the germination of the conidia of $A$. cariae by $100 \%$.
\end{abstract}

Keywords: Carica papaya; Asperisporium caricae; Acremonium sp; Hansfordia pulvinata.

Abbreviations: BDA_Potato, Dextrose and Agar; CRD_Completely Randomized Design; Pz_Enzymatic Activity; dc_diameter of the colony; dcp_zona de precipitação.

Introduction

The rapid population growth demands more food and agricultural production, requiring greater protection for plants using chemicals compounds against pests and diseases. However, this has serious consequences, both for the environment and the human health, especially farmers and consumers (Araújo and Oliveira, 2017). Besides, it is a barrier towards commercialization that is the exports of Brazilian fruits.

The Asperisporium caricae (Speg.) Maubl., causative agent of black spot, is broadly disseminated in papaya cultivation. It reaches both commercial and domestic orchards, which demands intensive fungicide applications to be controlled (Vawdrey et al., 2008; Barreto et al., 2011). The fungal infection, besides reducing the photosynthetic area, can directly affect the production and depreciation of the commercial value of the fruits (Adikaram e Wijepala, 1995; Ventura \& Rezende, 2016). Fruits covered with black spot are unmarketable for the more demanding internal and external markets. When it is commercialized for the lessdemanding consumer, it gets its value depreciated. Thus, markets that look for products with lower rates of pesticide residues request more sustainable cultivation systems (Dianese et al., 2008; Martileto et al., 2008; Poltronieri et al., 2017).

The use of biological control has been examined as an alternative measure of pathogen control. It can provide reduction of the pathogen population, complying with the market rules. It is a promising strategy in an integrated management component that allows addition of value to the products in the market. Biological control is a system that has been continuously investigated, being an important alternative for the control of different phytosanitary issues that occur in agriculture (Ahmed et al., 2003; Almeida et al., 2007). It is of interest to study the mechanisms of action of the antagonists to obtain a more effective biological control. The biological control is built on the antagonistic relation 
between microorganism and phytopathogens. It can be characterized by different modes of action such as competition for space and nutrients, antibiosis, mycoparasitism, predation and induction of resistance of the predation and induction of host plant resistance (Brunner et al., 2005; Harman, 2006; Harman, 2011).

Although there are fungi with potential of black spot biocontrol (Vivas et al., 2015), scarce information is available on the mode of action of the antagonistic fungi on $A$. caricae, specifically in papaya culture. Researches that test the antagonistic potential are important to support the development of biological control programs for papaya black spot. This work aimed at investigating the antagonistic activity of fungi with potential for the biocontrol of $A$. caricae. In here, the mycoparasitism, the enzymatic activity, and the production of volatile and non-volatile compounds were evaluated.

\section{Results and Discussions}

\section{Descriptive analysis of the in vitro mycoparasitism process} on the conidia germination of $A$. caricace

For the description of interaction events between the mycoparasite fungi and pathogen, we observed germination of the $A$. caricae conidia and mycoparasites 24 hours after test inoculation (Fig 2: A1, B1, C1, D1, E1, F1, and G1). After 48 and 72 hours, the isolates L-622 of L. lecanii (Fig 2: F2 and F3), S-599 of S. lanosoniveum (Fig 2: E2 and E3), A-598, A602 and A-617 of Acremonium sp (Fig 2: B2, B3, C2, C3, D2, and D4), and $\mathrm{H}-611$ of $\mathrm{H}$. pulvinata (Fig 2: $\mathrm{A} 2$ and $\mathrm{A} 3$ ) showed interweaving of their hyphae with the ones of $A$. caricae. This was not seen for hyphae of the isolate 1-609 of S. implicatum (Fig 2: G2 e G3).

Although the isolates of $L$. lecanii, S. lanosoniveum, $\mathrm{H}$. pulvinata and Acremonium sp, $H$. pulvinata established contact with the pathogen hyphae, differences among the different isolates were observed. For instance, $H$. pulvinada showed specialized structures similar to 'appressoria' (Fig 2: A3), which adhered to the germ tube of A. caricae. After 96 hours, the hyphae of the isolate H-611 were enveloped around the hyphae of the host, creating hook-like structures (Fig 2: A4).

The isolates A-598, A-602, and A-617 of the genus Acremonium sp., exhibited behavior similar to the mycoparasitism of $A$. caricae. These isolates showed a moreintense contact wrapping in the germ tube of the conidium of the pathogen (Fig 2: B3, C2, C3 D2, and D4). For the isolate of L. lecani (L-622), the events related above were also observed; however, with less activity. Besides, a reduction of the germ tube of $A$. caricae by that isolate was observed after 96 hours (Fig 2: F1, F2, F3, and F4).

The most effective mycoparasite fungus was the $\mathrm{S}$. lanosoniveum that showed the hyphae growth directed to the pathogen preventing its development. It was seen that the interweaving of the mycoparasite hyphae became dense after 96 hours, causing the penetration of the mycoparasite into the spores of $A$. caricae (Fig 2: E4). This isolate was aggressive, giving to that antagonist an enormous ability as a mycoparasite by means of the fast and intense colonization of the substrate, leading to the destruction of the cellular wall, probably to obtain nutrients from the dead cells. This observation matched the report by Martins-Corder and
Melo (1998), where they proved the in vitro antagonism of Trichoderma spp. (Verticillium dahlia). On the other hand, we did not see interweaving of the hyphae with conidium of the pathogen in the isolate of S. implicatum (I-609) (Fig 2: $\mathrm{G} 1, \mathrm{G} 2, \mathrm{G} 3$, and G4).

The fungi S-599, L-599, A-602, A-598, A-617, and H-611 showed characteristic of mycoparasitism. According to Almeida et al. (2007) and Harman (2011), the mechanism of mycoparasitism is a process of physical destruction, in which the antagonist detects and localizes hyphae of susceptible fungi growing towards it. This process happens because of the chemical stimuli produced by the hyphae that form structures similar to appressoria, wrapping to the full extent and then penetrate and digest the host hypha (Almeida et al., 2007; Harman, 2011).The fungi activity as mycoparasite is an important action mechanism of biocontrol agents because, when they attack the hyphae and proceed with reproduction and further affect their survival structures, they can reduce the infection and the inoculums level.

The growth and wrapping of the hyphae is important for the parasitic interaction; but it may not be sufficient to guarantee success in biological control. Some authors reported that the synergetic action attributed to the production of enzymes and antibiotics simultaneously may explain the best performance of the antagonistic action (Isaias et al., 2014).

\section{Hydrolytic enzyme production by mycoparasite fungi}

In the mycoparasitism, the extracellular enzymes play an important role in the hydrolysis of the phytopathogenic host by the antagonism, after the adherence process (Harman, 2000). Many enzymes, such as lipase and protease, are responsible for the hydrolysis of the cell walls of the host, enabling its invasion and nutrition by the mycoparasite (Suarez et al., 2004).

We could detect the activity of the lipase enzyme (Table 1) by the presence of the opaque halo around the colonies. That activity was observed in most of the tested fungi. They were the best values of the enzymatic index for the isolates A-602 (IE $=0.54)$ and $\mathrm{H}-611$ (IE = 0.59). The ratio value for the enzymatic index was lower than the ones obtained by the fungus Aspergillus sp. (the lower the value of the biological index, the greater the enzymatic activity), which demonstrates the great potential of those isolates concerning the activity of that enzyme.

The presence of halo was also observed for the isolates 609, A-598, and A-617; however, the enzymatic index was greater than the ones for the previous isolates. The isolates S-599 and L-622 did not produce enzymatic halo that indicated the ability to degrade lipase.

According to Hankin and Anagnostakis (1975), the opaque halo is from the formation of calcium crystals of lauric acid, released by the action of the enzyme or by complete degradation of the lipid salts in the medium containing sorbitol monolaurate (Tween 20 ) as the lipid substrate. As stated by Kolattukudy (1985), there is evidence that cutinase and lipase were able to degrade cutin. These enzymes were directly involved in fungus penetration through the cuticle, performing an important role in the pathogenicity.

Another enzyme, protease, can participate in the degradation of the structural cellular proteins to destabilize the cellular integrity of the phytopathogen (composed of 
Table 1. Activity of enzymes protease and lipase of Hansfordia pulvinata (H-611), Acremonium sp, (A-598, A-602 and A-617), Simplicillium lanosoniveum (S-599), Lecanicillium lecanii(L-622)and Sarocladium implicatum (I-609).

\begin{tabular}{|c|c|c|c|c|c|c|}
\hline \multirow{2}{*}{ Isolate } & \multicolumn{3}{|c|}{ Protease Activity } & \multicolumn{3}{|c|}{ LipaseActivity } \\
\hline & \multicolumn{2}{|c|}{ Halo $(\mathrm{cm})$} & Classification $^{1}$ & \multicolumn{2}{|c|}{ Index (ratio) } & Classification $^{2}$ \\
\hline $1-609$ & 1.35 & $A^{*}$ & ++ & 0.80 & D & + \\
\hline S-599 & 1.40 & A & ++ & 1.00 & $\mathrm{~F}$ & - \\
\hline L-622 & 1.16 & B & + & 1.00 & $\mathrm{~F}$ & - \\
\hline A-602 & 1.40 & A & ++ & 0.54 & A & ++ \\
\hline A-598 & 1.37 & A & ++ & 0.85 & $\mathrm{E}$ & + \\
\hline A-617 & 1.10 & B & + & 0.88 & $\mathrm{E}$ & + \\
\hline H-611 & 0.00 & $\mathrm{C}$ & - & 0.59 & B & ++ \\
\hline Aspergillus $\mathrm{sp}$ & 1.54 & A & ++ & 0.67 & C & + \\
\hline
\end{tabular}

* Means followed by the same lower case letter in the column do not differ significantly according to Scott-Knott test at $5 \% .{ }^{1}$ Classification according to the grouping of the means: negative $(-)$; positive $(+)$ and strongly positive $(++){ }^{2}$ Classification according to the value of the biologic index: $I B=1$, negative $(-) ; 0,64=I B<1$, positive $(+)$ and IB $<0,64$, strongly positive (++)

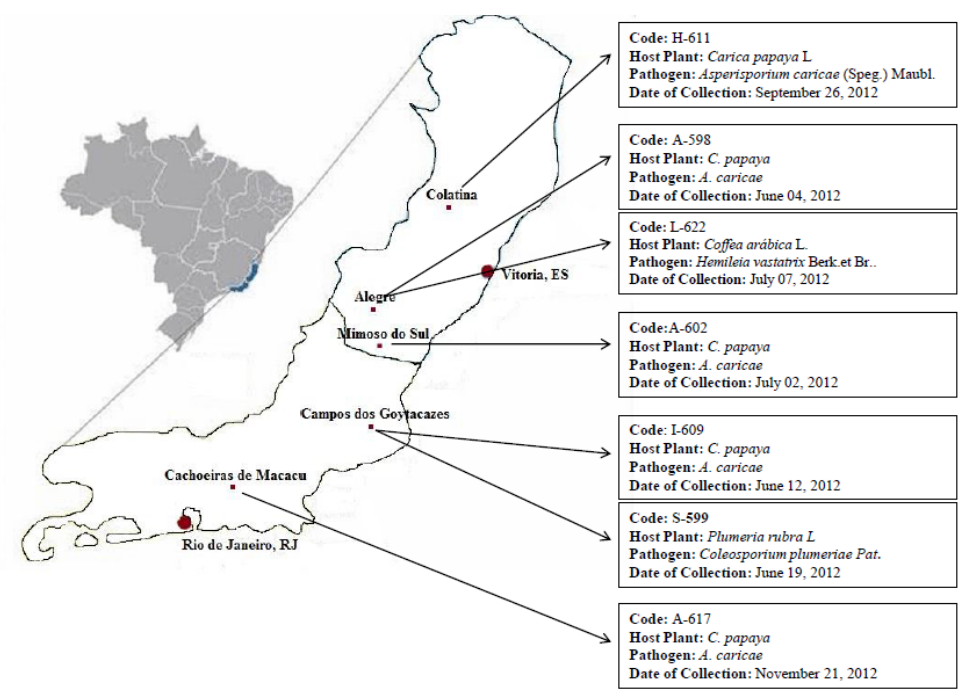

Fig 1. Relation among the isolates of potential mycoparasite fungi, local, date of collection, and substrate (pathogen) of origin. Code of isolates $\mathrm{A}=$ Acremoniumsp, $\mathrm{H}=$ Hansfordia pulvinata, $\mathrm{I}=$ Sarocladium implicatum, $\mathrm{L}=$ Lecanicillium lecanii and $\mathrm{S}=$ Simplicillium lanosoniveum

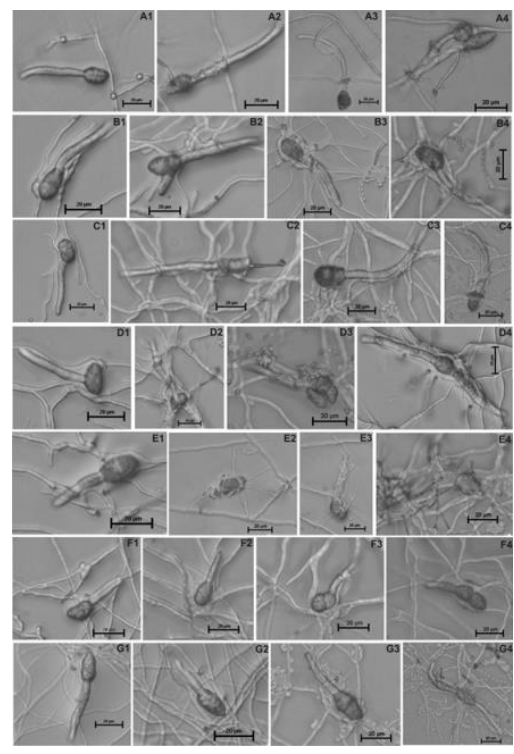

Fig 2. Description of in vitro events of mycoparasitism Hansfordia pulvinata $\mathrm{H}-611(\mathrm{~A} 1$ to A4), Acremonium sp, A-602, A-617 and A598(B1 to D4), Simplicillium lanosoniveum S-599 (E1 to E4), Lecanicillium lecanii L-622(F1 to F4), Sarocladium implicatum I-609 (G1 to G4) fungi on conidia of Asperisporium caricae, after $24 \mathrm{~h}(1), 48 \mathrm{~h}(2), 72 \mathrm{~h}(3)$ and $96 \mathrm{~h}(4)$. 


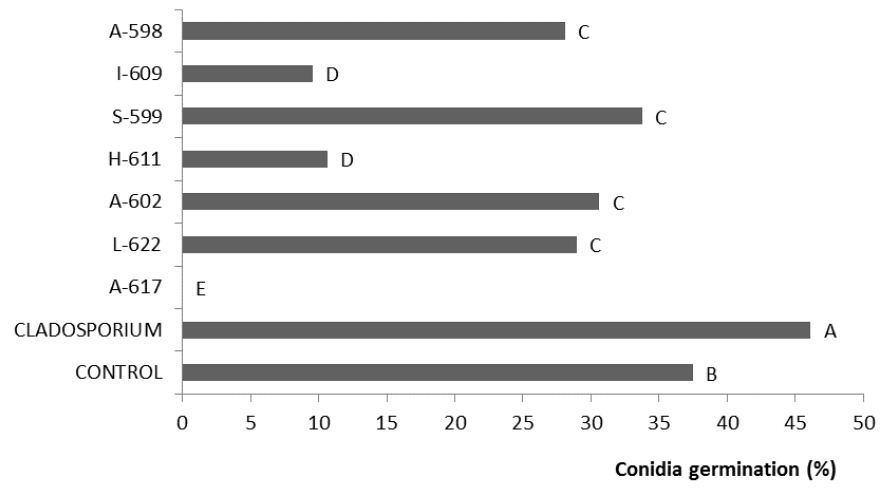

Fig 3. Effect of non-volatile compounds on the germination of $A$. caricae conidia produced by antagonistic fungi: Hansfordia pulvinata (H-611), Acremonium sp (A-598, A-602 and A-617), Simplicillium lanosoniveum (S-599), Lecanicillium lecanii (L-622), Sarocladium implicatum (I-609); and its controls (only the pathogen A. caricae and a fast growing fungus Cladosporium sp). Means followed by the same letter do not differ by Scott-knott at 0.05 of probability.

of chitin and glucans polymers, interspersed with proteins), facilitating the colonization by the antagonist (Howell, 2003, Suarez et al. 2004). A great proteolytic activity was observed in Aspergillus sp. fungus (with halo of $1.54 \mathrm{~cm}$ ). However, this was equal to the means found for the halos obtained for the isolates S-599, A-602, A-598, and I-609, presenting the best means for the enzymatic halos. This varied from 1.40 to $1.35 \mathrm{~mm}$ diameter, with the enzymatic activity classified strongly positive (Table 1). A second group with positive classification, was formed by L-622 (halo $=1.16 \mathrm{~cm})$ and A617 (halo $=1.10 \mathrm{~cm}$ ). The isolate H-611, of $\mathrm{H}$. pulvinata, did not form light halo, showing the evidence that the enzyme protease is being classified as negative enzymatic activity.

Betttiol (1991) reported that a biocontrol agent can act using one or more antagonistic interaction mechanisms. The synergistic action between hydrolytic enzymes and secondary metabolites offers a greater degree of antagonism to mycoparasite, rather than separate action of those two mechanisms (Benítez et al., 2004). This synergistic action increases the chances of success in biological control.

\section{Action of volatile and non-volatile compounds on conidial germination of $A$. caricae}

Antibiosis is the interaction among organisms, in which one or more metabolites produced by an organism has a harmful effect on the other (Stadnik and Bettiol, 2000). It may occur inhibition of growth and/or germination, which might be lethal to the host. The metabolite generated by the fungus may penetrate into the cell and inhibit its activity, causing lysis and dissolution of the cell by chemical toxicity (Ahmed et al., 2003). This happens regardless of physical contact among microorganisms and can occur by volatile metabolites and non-volatile metabolites.

The assay to evaluate the in vitro presence of volatile compounds showed that there was not any statistical difference between the means of conidial germination in the conducted tests. Therefore, in this test, there was no evidence that the isolates produce non-volatile compounds to be able to inhibit the germination of $A$. caricae. Some authors explained that the volatile antibiotic acts on the susceptible fungi by means of the inhibition of the mycelial growth. This means that isolate with ability to produce non- volatile substances do not always produce such volatile substances (Martins-Corder and Melo, 1998).

A similar result was observed in the reduction of conidium germination of $A$. caricae. The effect of non-volatile compounds diffused in culture medium showed that there was a reduction in conidial germination of $A$. caricae. In this test, we observed that the isolate A-617 of Acremonium sp. stood out by totally inhibiting the germination of $A$. caricae. A second group formed by the isolates I-609 and H-611 of $S$. implicatum and $H$. pulvinata respectively, demonstrated their ability to inhibit the conidial germination of $A$. caricae up to $10 \%$. Lastly, the isolates A-598, S-599, A-602, and L-622 of Acremonium sp, $S$. lanosoniveum and $L$. lecanii, respectively, inhibited germination up to $30 \%$ (Fig 3).

Martin-Corder and Melo (1998) reported the capacity of Trichoderma sp. to produce secondary metabolites but its fungal effect can vary among species, isolates of the same species, and according to the antifungal compounds they secrete (Sivasithamparam et al, 1998; Lorito et al., 2010). That can explain the variation of conidial germination of $A$. caricae by the volatile compounds found for the isolates of Acremonium sp.

For the fungi of the genus Acremonium sp and Hansfordia pulvinata, the presence of antibiosis and antifungal compounds in other pathosystems has been already reported. For instance, Tirilly et al. (1983) investigated the mechanism of mycoparasitism of $\mathrm{H}$. pulvinata on Cladosporium fulvum Cook. on tomato leaves and confirmed the in vitro presence of a sesquiterpene compound, (13desoxyphomenome), with fungistatic action. Wicklow et al. (2005) concluded that Acremonium zeae, which showed significant antifungal activity against Aspergillus flavus and Fusarium verticillioides, brought to light that the metabolites responsible for that activity were the pyrrocidin $A$ and $B$ antibiotics. Understanding the action of mechanisms involved in the antagonism of Acremonium sp., H. pulvinata, S. lanosoniveum, L. lecani and S. implicatum isolates on $A$. caricae, the causal agent of papaya black spot, is important to select and practically apply the more efficient biocontrol agents. The in vitro tests are among the first steps to select antagonistic agents to be applied in biological control programs. However, their potential should be further evaluated under field conditions. Our results present information that can stimulate future works on the potential 
of these mycoparasite fungi, which opens a perspective for a new option for alternative control of papaya black spot.

\section{Materials and Methods}

\section{Fungi species and isolates}

Seven isolates of fungi with potential of being mycoparasites were used: one isolate of Hansfordia pulvinata (H-611), three isolates of the genus Acremonium sp. (A-598, A-602, and A-617), one isolate of Sarocladium implicatum (I-609), one isolate of Lecanicillium lecanii (L-622), and one isolate of Simplicillium lanosoniveum (S-599) (Fig 1). The monosporic cultures were obtained and stored into tubes containing medium potato, dextrose and agar (BDA) inclined at $10 \circ \mathrm{C}$ according to Castellani method (Gonçalves et al., 2016).

\section{Description of in vitro mycoparasitism events in germinated conidia of $A$. caricae using optical microscopy}

The mycoparasite fungi (Fig 1) were grown in microculture together with the $A$. caricae conidia. A completely randomized design (CRD) with four replications was used. For the microscopic tests, Agar flux medium was placed under the surface of microscopy slides. After solidification of the medium, a suspension of $10^{4} \mathrm{conidia} / \mathrm{ml}$ of each genus mycoparasite fungus was placed on slides together with the suspension of $10^{4}$ conidia/ml of $A$. caricae. The slides were incubated in a humid chamber (Gerbox ${ }^{\otimes}$ ) at $25^{\circ} \mathrm{C}$, for $24 \mathrm{~h}$, $48 \mathrm{~h}, 72 \mathrm{~h}$ and $96 \mathrm{~h}$ after preparation and thern observed under the optical microscope. The antagonistic events were described accordingly.

\section{Hydrolytic enzyme production in solid medium by mycoparasite fungi}

We studied the production of lipase and protease enzymes for the mycoparasite fungi (Fig 1). The extracellular lipolytic activity was identified in culture medium as described in Cuzzi (2011). Four replications were applied. In all tests, 20 $\mathrm{mL}$ of culture medium were placed on Petri dishes. Subsequently, each species of mycoparasite was spiked to the center of the dishes and incubated in B.O.D. at $25{ }^{\circ} \mathrm{C}$ for 10 days.

To compose the medium, we used $0.38 \mathrm{~g}$ of $\mathrm{NaNO}_{3} ; 1.19 \mathrm{~g}$ of $\mathrm{KH}_{2} \mathrm{PO}_{4} ; 0.50 \mathrm{~g}$ of $\mathrm{MgSO}_{4} 7 \mathrm{H}_{2} \mathrm{O} ; 0.50 \mathrm{~g}$ of $\mathrm{KCl} ; 0.01 \mathrm{~g}$ of $\mathrm{FeSO}_{4} 7 \mathrm{H}_{2} \mathrm{O} ; 10 \mathrm{~g}$ of $\mathrm{C}_{6} \mathrm{H}_{12} \mathrm{O}_{6}$; and $20 \mathrm{~g}$ of Agar that were added to $1000 \mathrm{~mL}$ of distilled water and supplemented with $2 \%$ of Tween 20 (sorbitan monolaurate). The $\mathrm{pH}$ of the medium was adjusted to 6.5 .

The lipolytic activity was demonstrated by the presence of halo of calcium crystals of the lauric acid released by the enzymes around the colony. To determine the enzymatic activity (Pz), we applied the methodology described by Hankin and Anagnostakis (1975), in which the activity (Pz) of each evaluated species derived from the ratio between the diameter of the colony (dc) and the precipitation zone (dcp). The activities were classified as negative $(P z=1)$, positive $(0.64=\mathrm{Pz}<1)$ and strongly positive $(\mathrm{Pz}<0.64)$.

For the protease activity, the tests were performed according to the methodology reported by Dingle et al. (1953). A liquid medium was initially prepared aiming at stimulating the enzyme secretion. The medium was composed of $3.5 \mathrm{~g}$ of $\left(\mathrm{NH}_{4}\right)_{3} \mathrm{PO}_{4} ; 0.75 \mathrm{~g}$ of $\mathrm{K}_{2} \mathrm{HPO}_{4} ; 0.2 \mathrm{~g}$ of $\mathrm{CaCl}_{2} .2 \mathrm{H}_{2} \mathrm{O} ; 1,25 \mathrm{~mL}$ of salt trace solution $\left(0.1 \mathrm{~g}\right.$ of $\mathrm{FeSO}_{4} ; 0.1 \mathrm{~g}$ of $\mathrm{MnCl}_{2} ; 0.1 \mathrm{~g}$ of $\mathrm{ZnSO}_{4}$ in $100 \mathrm{~mL}$ of distilled water); $50 \mathrm{~mL}$ of solution of $\mathrm{C}_{6} \mathrm{H}_{12} \mathrm{O}_{6}$ at $30 \%$; and $0.25 \mathrm{~g}$ of $\mathrm{MgSO}_{4}$, which were added into the $500 \mathrm{~mL}$ of distilled water.

The induction substrates of $1.25 \mathrm{~g}$ skimmed milk powder plus $1.25 \mathrm{~g}$ gelatin (protease) were added to this medium, and the $\mathrm{pH}$ was adjusted to 7.0. The medium was transferred to Erlenmeyer flasks, where two discs of $7 \mathrm{~mm}$ of culture medium containing fungal mycelium were added. The treatments were incubated on orbital shaker and agitated at $120 \mathrm{rpm}$ at $25^{\circ} \mathrm{C} \pm 2{ }^{\circ} \mathrm{C}$ for ten days. After that period, the culture mediums were filtered through qualitative filter paper to separate the mycelium. The obtained filtrate was used in the enzymatic activity tests.

In the test of enzymatic activity of protease, a solid medium was prepared with $1.8 \mathrm{~g}$ of Agar and $1 \mathrm{~g}$ of powdered milk dissolved in $100 \mathrm{~mL}$ of distilled water, sterilized and distributed in Petri dishes. Circular perforations with diameter of $0.5 \mathrm{~cm}$ were made and added to $50-100 \mu \mathrm{L}$ filtrate of the induction medium. Then the dishes were incubated in an oven at $25{ }^{\circ} \mathrm{C}$ for 24 hours. The protease activity was measured by the formation of the colorless halo from the hydrolysis of the milk casein around the application point of the filtrate. The comparative evaluation of the enzymatic activity was determined by the diameter of the halo.

Data from the enzymatic activity were subjected to oneway analysis of variance and the means were compared (Scott-knott at 0.05 of probability) using the Genes program (Cruz, 2013).

In vitro evaluation of volatile and non-volatile compounds in the spore germination of $A$. caricae

The in vitro tests for antagonism were executed by evaluation of conidial germination due to the slow growth of A. caricae in culture medium. We placed a holder (Agar fragments) to assess the action of volatile compounds on the culture of each mycoparasite with 10 days' incubation in BDA medium at $25{ }^{\circ} \mathrm{C}$ and photoperiod of 12 hours. Above it, we placed glass slides that contained Agar disc of $7 \mathrm{~mm}$. After that, a suspension of $10^{4}$ conidia. $\mathrm{ml}^{-1}$ of $A$. caricae was added to the discs. The Petri dish of each mycoparasite was hermetically sealed with Parafilm ${ }^{\circledR}$ and maintained in B.O.D., where they remained until evaluation.

The isolates were cultured on sterilized cellophane paper overlaid on the BDA medium in Petri dish to study the antibiosis by non-volatile compounds. After 10 days of incubation, at $25{ }^{\circ} \mathrm{C}$ and photoperiod of 12 hours, the cellophane was removed from the surface of the medium and discarded together with the culture of the antagonistic. Discs of $7 \mathrm{~mm}$ of the BDA medium were removed from the culture, where the mycoparasites were grown. It was placed on the slide of the microscope; and subsequently, a suspension of $10^{4}$ conidia.ml $l^{-1}$ of $A$. caricae was added. The slides were placed on Petri dish sealed with Parafilm ${ }^{\circledR}$ and incubated in B.O.D., where they remained until evaluation.

The tests were done twice. We applied the randomized complete block design with 9 treatments (7 isolates +1 control +1 negative control) and 4 replications, both for the volatile and the non-volatile compound tests. We used dishes without fungal growth as controls. We applied the 
pre-cultivation of Cladosporium sp. as negative control, which is considered a fast-growing fungus. By this, we aimed to understand whether there is effect of volatile compound or there was an effect of accumulation of carbon dioxide from breathing that prevented the $A$. caricae germination. The germinated and non-germinated conidia were counted in three fields at the optical microscope at 20x magnification, after 24 hours of incubation. They were compared with control (BDA medium without prior antagonist culture) and negative control (Cladosporium $s p$ ). The germination data of the $A$. caricae conidia were subjected to analysis of variance with factorial arrangement. We conducted individual variance analyses and test of mean comparisons (Scott-knott at 0.05 of probability) using Genes program when a significant effect of the interaction isolates $x$ tests (Cruz, 2013) was found.

\section{Conclusion}

The isolates A602, A-598, A-617, H-611, I-609, and L-622 presented mycoparasitism behavior and acted efficiently, when antagonizing the phytopathogen $A$. caricae. Protease activity was strongly positive for the isolates of I-609, S-599, A-602, and A-598 and as positive for the isolates of L-622 and $A-617$. For lipase activity, the isolates that presented to be strongly positive were $\mathrm{H}-611$ and $\mathrm{A}-602$; and as positive, A-598, A-617, and 1-609. There was production of nonvolatile compounds by the antagonist, highlighting the isolates A-617, which completely inhibited germination of $A$. caricae. The isolates of Acremonium sp, $H$. pulvinata, $S$. lanosoniveum, L. lecanii and $S$. implicatum selected using mycoparasitism test, enzymatic activity and non-volatile compound test. The results showed a great potential for antagonizing the $A$. caricae in vitro.

\section{Acknowledgements}

The authors thank the Darcy Ribeiro North Fluminense State University - UENF and National Council for Scientific and Technological Development - CNPq, for financial support.

\section{References}

Adikaram NKB, Wijepala M (1995) Asperisporium black spopt in Carica papaya: a new disease in Sri Lanka. J Nat Sci. Foundation Sri Lanka. 23(4): 213-219.

Ahmed AS, Ezziyyani C, Sánchez CP, Candela ME (2003) Effect of chitin on biological control activity of Bacillus spp. and Trichoderma harzianum against root rot disease in pepper (Capsicum annum) plants. Eur J Plant Pathol. 109: 633-637.

Ameida FB, Cerqueira FM, Silva R.N, Ulhoa CJ, Lima, AL (2007) Mycoparasitism studies of Trichoderma harzianum strains against Rhizoctonia solani: evaluation of coiling and hydrolytic enzyme production. Biotechnol Lett. 29: 11891193.

Araujo IMM, Oliveira, ÂGRC (2017) Agronegócio e agrotóxicos: impactos à saúde dos trabalhadores agrícolas no nordeste brasileiro. Trab Edu Saúde. 15(1): 117-129.

Barreto LF, Savan PAL, Lima LL, Lodo BN (2011) Avaliação de fungicidas no controle de Asperisporium caricae na cultura do mamoeiro. Rev Bras Frutic. 33(spe1): 399-403.
Benítez T, Rincon AM, Limon MC, Codon, AC (2004) Biocontrol mechanisms of Trichoderma strains. Int Microbiol. 7: 249260.

Bettiol W (1991) Seleção de microrganimo antagônicos a fitopatógenos. In: Bettiol, W.(Org). Controle biológico de doença de plantas. Embrapa Centro Nacional de Pesquisa de defesa da Agricultura, Jaquariúna.

Brunner K, Zeilinger S, Ciliento R.; Woo SL, Lorito M, Kubicek $\mathrm{CP}$, Mach RL (2005) Improvement of the fungal biocontrol agent Trichoderma atroviride to enhance both antagonism and of plant systemic disease resistance. Appl Environ Microbiol. 71: 3959-3965.

Cruz CD (2013) GENES - a software package for analysis in experimental statistics and quantitative genetics. Acta Sci Agron. 3(5): 271-276.

Cuzzi C, Link S, Vilani A, Onofre SB (2011) Enzimas Extracelulares Produzidas por Fungos Endofíticos Isolados de Baccharis dracunculifolia D.C. (asteraeceae)., GI. Sci Technol. 4(2): 47-57.

Dianese AC, Blum, LEB, Dutra JJ, Lopes LF, Sena MC, Freitas LF (2008) Avaliação do efeito de fosfitos na redução da varíola (Asperisporium caricae) do mamoeiro (Carica papaya). Rev Bras Frutic. 30(3): 834-837

Dingle J, Reid WW, Solomons GL (1953) The enzymatic degradation of pectin and other polysaccharides. II. Application of the "cup-plate" assay to the estimation of enzymes. J Sci Food Agr. 4: 149-155.

Gonçalves RC, Alfenas AC, Mafia RG (2016) Armazenamento de microorganismo em cultura com ênfase em fungos fitopatogênicos. In: Alfenas AC, Mafia RG. Métodos em Fitopatologia. Publisher UFV, Viçosa

Hankin L, Anagnostakis SL (1975) The use of solid media for detection of enzyme production by fungi. Mycologia. 67 (3): 597-607.

Harman GE (2011) Multifunctional fungal plant symbionts: new tools to enhance plant growth and productivity. New Phytol. 189(3): 647-9.

Harman GE (2006) Overview of Mechanisms and uses Trichoderma spp. Phytopathology. 96(2): 190-194.

Harman GE (2000) Myths and dogmas of biocontrol. Changes in perceptions derived from research on Trichoderma harzianum T-22. Plant Dis. 84(4): 376-393.

Kolattukudy PE (1985) Enzymatic penetration of the plant cuticule by fungal pathogens. Ann Rev Phytopathol. 23: 223250.

Lorito M, Woo SL, Harman GE, Monte E (2010) Translational research on Trichoderma: from 'omics to the field. Ann Rev Phytopathol. 48: 395-417.

Martelleto LAP, Ribeiro RLD, Sudo-martelleto M, Vasconcellos, MAS, Marin SLD, Pereira MB (2008) Cultivo orgânico do mamoeiro 'Baixinho de Santa Amália' em diferentes ambientes de proteção. Rev Bras Frutic. 30(3): 662-666.

Martins-corder MP, Melo IS (1998) Antagonismo in vitro de Trichoderma spp. A Verticillium dahliae kleb. Sci Agric. 55(1): 1-7.

Poltronieri TPS, Silveira SF, Vivas M, Catarina RS, Cortes DFM, Azevedo AON, Pereira MG (2017) Selecting black-spot resistant papaya genotypes derived from backcrossing and hybrids. Genet Mol Res. 16(1): 1-11.

Saias CO, Martins I, Silva JBT, Silva JP, Mello SCM (2014) Ação antagônica e de metabólitos bioativos de Trichoderma spp. contra os patógenos Sclerotiumrolfsii e Verticillium dahliae. Summa Phytopathol. 40(1): 34-41. 
Sivasithamparam K, Ghisalberti EL (1998) Secondary Metabolism in Trichoderma and Gliocladium . In: Kubicek CP, Harman GE Trichoderma and Gliocladium. Basic Biology, Taxonomy and Genetics. Taylor and Francis, London.

Stadnik MJ, Bettiol W (2000) Controle biológico de oídeos. In: Melo IS, Azevedo JL. Controle biológico, Embrapa Meio Ambiente, Jaguariúna.

Suarez B, Rey M, Castillo P (2004) Isolation and characterization of PRA1, a trypsin-like protease from the biocontrol agent Trichoderm harzianum CECT 2413 displaying nematicidal activity. Appl Microbiol Biotechnol. 65(1): 46-55.

Tirilly Y, Kloosterman J, Bosch SG, van den JJK (1983) A fungi toxic Sesquiterpene from Hansfordia pulvinata. Phytochemistry. 22(9): 2082-2083.
Vawdrey LL, Grice KRE, Westerhuis D (2008) Field and laboratory evaluations of fungicides for the control of brown spot (Corynespora cassiicola) and black spot (Asperisporium caricae) of papaya in far north Queensland, Australia. Australas Plant Pathol. 37(6): 552-558.

Vivas JMS, Vivas M, Silveira SF (2015) Efeito da temperatura sobre o crescimento e esporulação in vitro de fungos hiperparasitas de Asperisporium caricae. Pesqui Agropecu Trop. 45(1): 73-81.

Ventura JÁ, Rezende JAM (2016) Doenças do Mamoeiro. In: Amorim L, Bergamim Filho A, Camargo LFA, Rezende JAM. Manual de Fitopatologia: Doenças das plantas cultivadas. Agr. Ceres. São Paulo

Wicklow DT, Roth S, Deyrup ST, Gloer JB (2005) A protective endophyte of maize: Acremonium zeae antibiotics inhibitory to Aspergillus flavus and Fusarium verticillioides. Mycol Res. 109(05): 610-618 